\title{
Aplikasi Wireless Sensor Network Untuk Pembacaan Meteran Air
}

\author{
Nugra Arsyistawa, Muhammad Rivai, dan Suwito \\ Departemen Teknik Elektro, Fakultas Teknologi Elektro, Institut Teknologi Sepuluh Nopember \\ e-mail:muhammad_rivai@ee.its.ac.id
}

\begin{abstract}
Abstrak - Pada era modern, manusia cenderung lebih menyukai hal yang praktis yang dapat mempermudah pekerjaan manusia. Untuk mewujudkan efisiensi yang diinginkan, manusia memanfaatkan teknologi untuk memudahkan pekerjaanya. Pada dunia Industri, efisiensi dapat menentukan biaya operasi perusahaan yang pada akhirnya berdampak pada penghasilan perusahaan. Salah satu peluang pemanfaatan teknologi untuk memudahkan pekerjaan manusia adalah sistem monitoring penggunaan meteran air yang dapat diakses secara online sehingga tidak membuang waktu untuk mencatat penggunaan secara manual. Pada penelitian ini merancang jenis perangkat meteran baru yang memanfaatkan teknologi nirkabel untuk mengirim sinyal listrik yang terbaca oleh sensor aliran air FS300A G3/4 yang bekerja dengan prinsip hall-effect. Sensor dikalibrasi dengan mengambil data berupa pulsa untuk menghitung aliran air. Mikrokontoler Arduino Uno akan memproses sinyal yang terbaca oleh sensor dan menampilkanya pada LCD. Perangkat terhubung dengan dalam jaringan wireless sensor network menggunakan modul Xbee S1 dengan tipe topologi jaringan digimesh yang memungkinkan proses data forwarding, yaitu proses pengiriman data dari node ke webserver melalui beberapa node sebagai jembatan. Dalam sistem ini Raspberry Pi model B digunakan sebagai webserver untuk mengumpulkan data dan mengirimnya pada server thingspeak.com tiap 30 detik. Berdasarkan hasil pengujian diketahui hubungan jumlah pulsa terhadap besar debit air, dan diketahui jangkauan maksimal dari node adalah 34 meter. Dalam uji coba jaringan, Node dengan jarak $20 \mathrm{~m}$ memiliki tingkat kesuksesan pengiriman data $99 \%$. Diharapkan dengan adanya alat ini, konsumsi air dapat dipantau secara lebih mudah dan efisien.
\end{abstract}

Kata Kunci-Meteran air, Wireless Sensor Network, Raspberry pi.

\section{PENDAHULUAN}

A IR merupakan kebutuhan primer dalam kehidupan seharihari manusia. Air dibutuhkan manusia untuk kebutuhan tubuh dan kebutuhan diluar tubuh. Tubuh manusia terdiri dari $70 \%$ air, oleh karena itu air merupakan elemen penting dalam keberlangsungan hidup manusia. Diluar tubuh manusia, air dapat digunakan untuk berbagai keperluan, mulai dari mencuci, mandi, masak dan lain-lain. Keberadaan air di bumi berkaitan dengan adanya siklus cuaca. Pada musim kemarau misalnya, siklus cuaca menjadi berubah yang mengakibatkan tidak terbentuknya awan-awan yang dapat menghasilkan hujan, dengan demikian suatu daerah dapat mengalami kekeringan selama musim kemarau. Berdasarkan data yang dirilis oleh Direktorat Jenderal Sumber Daya Air pada Desember 2014, lima waduk penampung air untuk wilayah Jawa Timur berada pada posisi deficit [1]. Di kota-kota besar, persediaan air memang sudah mencukupi. PT. PDAM sebagai penyedia layanan air telah menyediakan layanan air yang didistribusikan ke rumah-rumah penduduk melalui pipa-pipa distribusi yang kemudian dipasang meteran air untuk menghitung pemakaian air tiap rumah. Untuk membaca meteran tersebut diperlukan tenaga manusia untuk mencatat nominal angka secara manual.

Pada dunia industri, pembacaan meteran air juga dibutuhkan. Misalnya pada mesin pencampur, dapat ditambahkan meteran air yang terintegrasi. Selama ini penggunaan meteran air dalam industri dicatat secara manual. Dibutuhkan teknologi meteran air yang efisien dan mudah digunakan, sehingga dapat dilakukan penghematan dana dan tenaga operasional sebuah industri.

Berdasarkan permasalahan diatas dapat dirancang sebuah perangkat meteran air yang terintegrasi dalam jaringan WSN sehingga penggunaan air dapat dipantau dengan lebih mudah.

\section{TEORI PENUNJANG}

\section{A. Waterflow Sensor FS300A}

Water flow sensor pada dasarnya adalah sensor yang memanfaatkan prinsip hall effect. Hall effect dirancang untuk mendeteksi adanya objek magnetis dengan perubahan posisi suatu benda. Perubahan medan magnet yang terus menerus menyebabkan timbulnya pulsa yang kemudian memiliki frekuensi yang dapat di kalibrasikan sesuai dengan keperluan. Tegangan keluaran yang dari sensor hall effect tergantung kepada kerapatan flux magnet, jenis dan dimensi material yang digunakan, perbandingan arah antara jenis senyawa hall effect dan arah dari flux dan kerapatan magnet, arah dari arus yang melalui sensor dan sudut antara senyawa yang diukur dan flux magnet [2]. Keluaran dari sensor ini merupakan pulsa digital yang dapat diolah oleh mikrokontroler menjadi satuan air. Cara kerja sensor ditunjukan oleh Gambar 1.

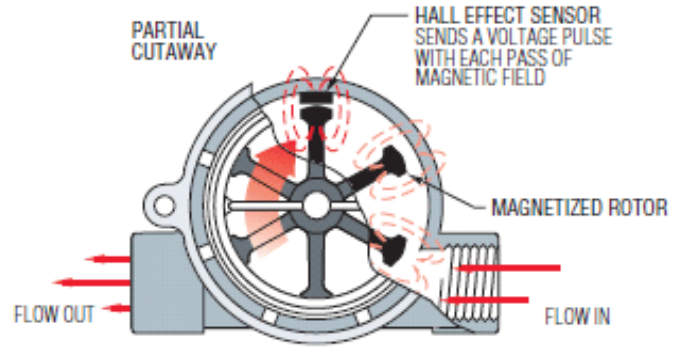

Gambar 1. Prinsip Kerja Sensor Waterflow 
Dalam perangkat sensor terdapat turbin kecil yang berputar sesuai dengan jumlah air yang melalui sensor. Pada turbin terdapat magnet yang mengubah polaritas tegangan keluaran sensor. Dengan begitu sensor memiliki keluaran berupa pulsa listrik. Sensor aliran air bekerja pada tegangan $5 \mathrm{~V}-18 \mathrm{~V}$, dengan jangkauan debit air 1-60 L/menit.

\section{B. Mikrokontroler Arduino Uno}

Uno merupakan salah satu perangkat mikrokontroler singleboard yang bersifat open-source, artinya produsen perangkat ini membuka source code dari perangkat tersebut sehingga pengguna dapat mengetahui dan mengembangkan cara kerja dari perangkat tersebut. Arduino UNO menggunakan prosesor Atmel AVR. Bahasa pemrograman yang digunakan Arduino UNO adalah bahasa $\mathrm{C} / \mathrm{C}++$ yang sudah disederhanakan. Pola pemrograman yang digunakan juga tidak jauh berbeda yaitu dengan pola Wiring (syntax dan library). Pemrograman pada Arduino UNO dilakukan melalui perangkat lunak IDE (integrated development environment) yang dirancang untuk mendukung penggunaan perangkat Arduino.

Arduino Uno adalah board mikrokontroler berbasis ATmega328. Uno memiliki 14 pin digital input/output (dimana 6 pin dapat digunakan sebagai output PWM), 6 input analog, resonator keramik $16 \mathrm{MHz}$, koneksi USB, jack listrik, header ICSP, dan tombol reset. Uno dibangun berdasarkan apa yang diperlukan untuk mendukung mikrokontroler, sumber daya bisa menggunakan power USB (jika terhubung ke komputer dengan kabel USB) dan juga dengan adaptor atau baterai. Arduino Uno juga memiliki fitur Atmega16U2 yang diprogram sebagai konverter USB-to-serial.

Pinout yang ada dalam Arduino memiliki fungsi yang berbeda. Pin analog digunakan untuk I/O berupa nilai tegangan yang akan dikonversi melalui ADC. Sedangkan pin digital digunakan untuk I/O berupa pulsa atau sinyal PWM. Selain itu ada pin TXD/RXD yang digunakan untuk berkomunikasi dengan perangkat lain secara serial. Selain itu juga dapat digunakan Pin SCL dan SDA yang digunakan untuk komunikasi I2C. Pin interrupt digunakan untuk intrupsi dalam program.

\section{Transciever Xbee}

Xbee adalah sebuah merk dari modul komunikasi radio frekuensi yang diproduksi oleh Digi International, ditunjukkan pada Gambar 2. Pada awalnya radio Xbee pertama diproduksi oleh merk MaxStream berdasarkan standard IEEE 802.15.4 tahun 2003 yang dirancang unutuk komunikasi point to point dan komunikasi star dengan kecepatan transfer data $250 \mathrm{~kb} / \mathrm{s}$. Modul Xbee dapat melakukan komunikasi antara satu dengan lainnya tanpa melalui kabel (wireless). Modul xbee cocok digunakan pada aplikasi-aplikasi yang memerlukan komunikasi antar modul namun memiliki kesulitan pada proses pemasangan kabel Xbee diproduksi dalam berbagai pilihan antena, diantaranya dengan konektor U.FL antena, Chip antenna, wire antenna, PCB antenna dan RPSMA antenna.

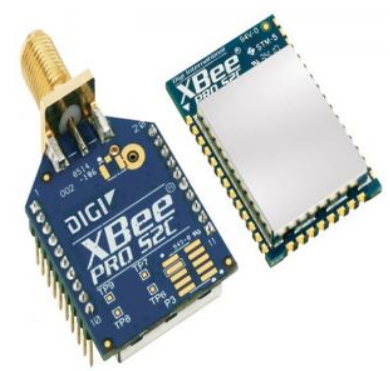

Gambar 2. Contoh modul transceiver Xbee

Modul komunikasi Xbee memiliki 20 pin yang memiliki fungsi berbeda-beda, diantaranya adalah VCC, Data in/out, Reset, Ground, pin input output (I/O) analog dan digital, PWM, VREF, dan lainya. Modul komunikasi ini bekerja dengan daya $3.3 \mathrm{~V}$ dan melakukan komunikasi data input output melalui serial (UART) [3]. Salah satu keunggulan modul komunikasi ini adalah banyaknya pin input output sebanyak 6 buah, dan memungkinkan untuk melakukan komunikasi data tanpa harus diproses oleh bantuan mikrokontroler.

\section{Wireless Sensor Network (WSN)}

Jaringan sensor nirkabel atau lebih sering disebut dengan istilah Wireless Sensor Network (WSN) merupakan suatu jaringan nirkabel yang terdiri dari beberapa node sensor yang disebar di suatu area tertentu untuk membentuk suatu jaringan yang dapat digunakan untuk memantau suatu kondisi fisik atau lingkungan, ditunjukkan pada Gambar 3. Setiap node sensor memiliki kemampuan untuk mengumpulkan data dan informasi untuk kemudian dikirimkan kepada webserver/base station. WSN adalah suatu infrastruktur jaringan wireless yang menggunakan sensor untuk memantau kondisi fisik atau kondisi lingkungan yang dapat terhubung ke jaringan. Teknologi Wireless Sensor Network memungkinkan peneliti untuk memperoleh suatu informasi yang lengkap mengenai suatu kondisi tanpa harus berada di sekitar area sensor. Informasi dapat diakses dari jarak jauh melalui perangkat seperti laptop, smartphone, remote control dan sebagainya. Beberapa keuntungan yang bisa diperoleh dari teknologi WSN adalah praktis dan ringkas karena tidak diperlukan adanya instalasi kabel yang rumit dan membutuhkan waktu lama, dan dalam kondisi geografi tertentu sangat menguntungkan dibandingkan dengan Wired Sensor. Keuntungan lainya dari teknologi ini adalah memungkinkan adanya usaha kooperatif dari node sensor.

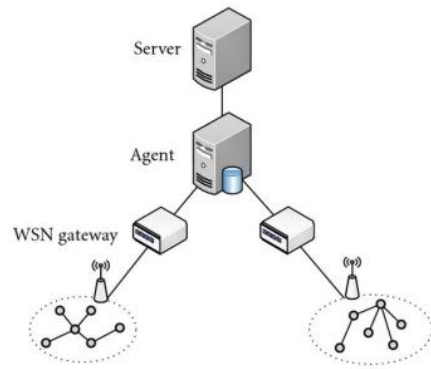

Gambar 3. Ilustrasi Jaringan WSN. 
Node dalam jaringan WSN dapat bekerja sama untuk meringankan proses komputasi data [4]. Untuk melakukan komunikasi dengan teknologi Wi-Fi digunakan standard komunikasi IEEE. Salah satu standard IEEE yang sering digunakan adalah keluarga IEEE 802.11. Standard komunikasi ini sudah digunakan sejak tahun 1985 oleh pemerintah Amerika Serikat. Teknologi jaringan ini merupakan yang paling umum digunakan. Ada beberapa pita frekuensi yang diguakan oleh 802.11 yaitu $2,5 \mathrm{GHz}$ dan $5 \mathrm{GHz}$. Frekuensi 2,5 $\mathrm{GHz}$ digunakan oleh IEEE $802.11 \mathrm{~b}$ dan $802.11 \mathrm{~g}$, sedangkan frekuensi $5 \mathrm{GHz}$ digunakan oleh IEEE 802.11a [5]. Pada standard komunikasi 802.11 data rate yang besar dan melebihi dari yang dibutuhkan menyebaban kebutuhan daya pada standard ini lebih besar. Untuk itu sudah diciptakan standard komunikasi yang baru yang sesuai dengan kriteria wireless sensor network yaitu IEEE 802.15.4. Standard komunikasi ini dirancang khusus untuk komunikasi dengan data rate rendah (250 kbit/s). Standard ini memungkinkan penghematan daya yang sangat besar dibandingkan dengan standard komunikasi sebelumnya.

\section{E. Raspberry Pi}

Raspberry Pi (juga dikenal sebagai RasPi) adalah sebuah SBC (Single-Board Computer) seukuran kartu kredit yang dikembangkan oleh Yayasan Raspberry Pi di Inggris (UK) dengan maksud untuk mengembangkan pengajaran ilmu komputer di sekolah-sekolah.

Pada Gambar 4 Raspberry Pi menggunakan system on a chip (SoC) dari Broadcom BCM2837, juga sudah termasuk prosesor Quad Corter A53 1.2 GHz, GPU VideoCore IV dan SDRAM sebesar 1GB (untuk Rev. B) [6]

\section{F. Analisa Free Space Path Loss}

Untuk membangun sebuah jaringan komunikasi yang ideal terdapat beberapa faktor yang patut diperhitungkan. Jaringan komunikasi yang baik tentunya memiliki sistem transmisi jaringan yang ideal pula. Kualitas sistem transmisi yang ideal dapat dipengaruhi oleh banyak hal, mulai dari jarak transmisi, jenis area transmisi, banyaknya distraksi dan interferensi dan sebagainya. Untuk menentukan kualitas transmisi dalam sebuah jaringan dapat diukur menggunakan analisa pathloss dan budget link.

Pathloss adalah suatu metode yang digunakan untuk mengukur suatu loss sinyal yang disebabkan oleh cuaca, kontur tanah, kondisi medan transmisi dan lain-lain, agar tidak menggangu pemancaran antar 2 buah antenna yang saling berhubungan. Nilai pathloss menunjukkan level sinyal yang melemah (mengalami attenuation) yang disebabkan oleh propagasi free space seperti refleksi, difraksi, dan scattering.

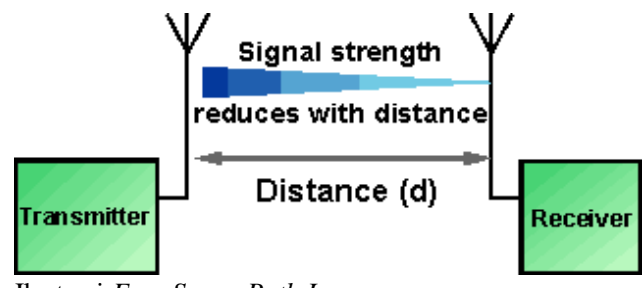

Gambar 4. Ilustrasi Free Space Path Loss.
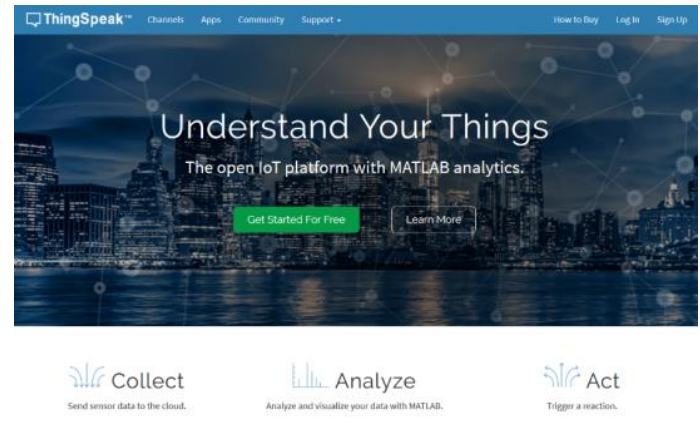

Gambar 5. Tampilan laman web thingspeak.

Path loss sangat penting dalam perhitungan Link Budget, ukuran cell, ataupun perencanaan frekuensi. Faktor-faktor yang mempengaruhi nilai level daya dan pathloss adalah jarak pengukuran antara $\mathrm{Tx}$ dan Rx, tinggi antena (Tx dan Rx), serta jenis area pengukuran.

\section{G. Thing Speak}

Thing speak adalah open source "internet of things" atau biasa disingkat IOT aplikasi dan API untuk menyimpan dan mengambil data menggunakan HTTP melalui internet, ditunjukkan pada Gambar 5. Beberapa fitur dari thingspeak diantaranya: Open API, mengoleksi data real-time, menampilkan geolokasi data, memproses data melalui matlab, visualisasi data dan tambahan plugins.

Internet of Things (IOT) menyediakan akses ke berbagai perangkat embedded dan layanan web. ThingSpeak adalah platform IOT yang memungkinkan kita untuk mengumpulkan, menyimpan, menganalisis, memvisualisasikan, dan bertindak atas data dari sensor atau aktuator, seperti Arduino, Raspberry $\mathrm{Pi}$, BeagleBone Hitam, dan perangkat keras lainnya. Misalnya, dengan ThingSpeak kita dapat membuat aplikasi sensorlogging, aplikasi pelacakan lokasi.ThingSpeak berfungsi sebagai pengumpul data yang mengumpulkan data dari perangkat node dan juga memungkinkan data yang akan diambil ke dalam lingkungan perangkat lunak untuk analisis historis data.

\section{PERANCANGAN SISTEM}

Pada penelitian ini dirancang sebuah sistem yang terdiri dari 2 buah node dan 1 buah webserver. Diagram blok sistem ditunjukan oleh Gambar 6.

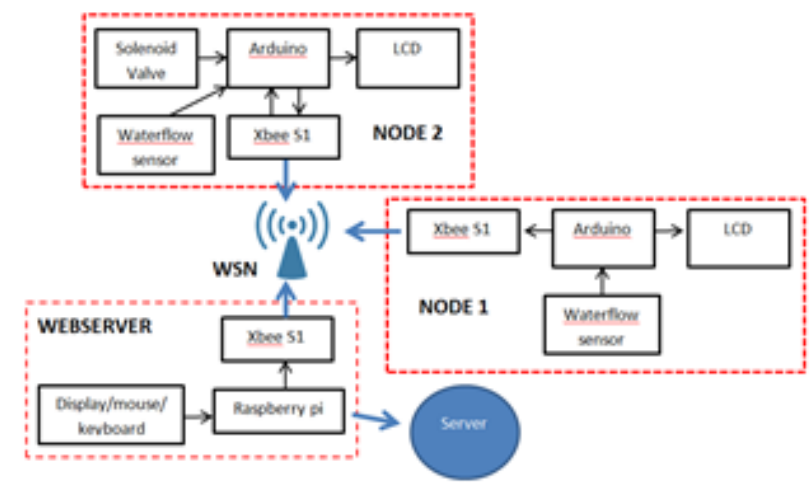

Gambar 6. Diagram blok sistem secara keseluruhan. 


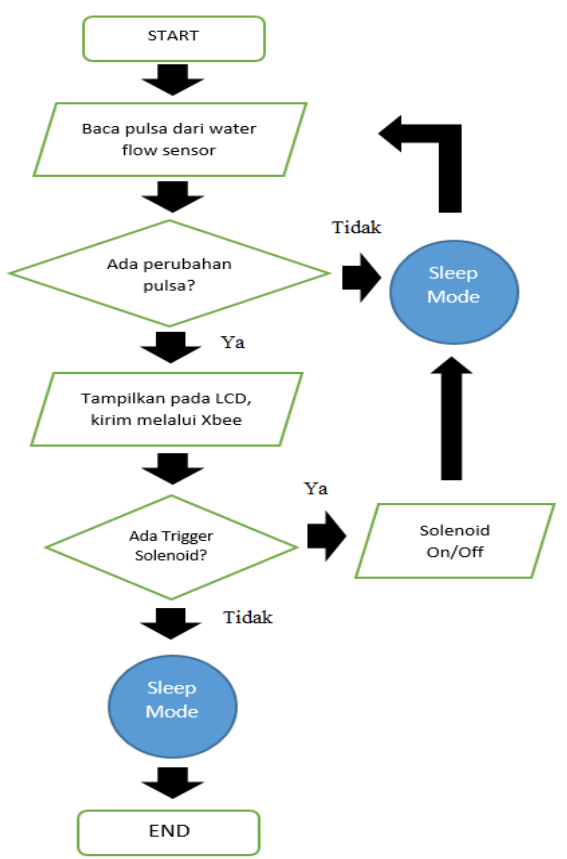

Gambar 7. Flowchart sistem pada node.

Node sensor pada sistem berfungsi mengkonversi pulsa listrik dari sensor dan mengirimkanya ke jaringan WSN melalui modul Xbee. Sistem ini menggunakan protokol digimesh yang memungkinkan adanya komunikasi antar node dengan topologi mesh yang setiap node nya bersifat homogeny. Sedangkan Webserver bertugas menerima data dari tiap node dan mengirimkanya ke thingspeak. Penjelasan lebih lanjut pada sub-bab berikut.

\section{A. Perancangan Node Sensor}

Node dirancang menggunakan mikrokontroler arduino uno sebagai prosesor dari data. Sensor aliran air FS300A menghasilkan pulsa yang berbanding lurus dengan kecepatan rotasi rotor dalam sensor tersebut. Saat air melewati sensor, pulsa-pulsa akan dihasilkan oleh sensor yang kemudian akan diproses oleh mikrokontroler. Pulsa tersebut dikonversi ke besaran flowrate $(\mathrm{L} / \mathrm{m})$ dan volume (Liter) lalu ditampilkan pada LCD dan dikirim ke webserver melalui xbee. Untuk mengkonversi pulsa digunakan rumus 1 .

$$
\mathrm{V}=\frac{P x T}{C x 60}
$$

Dimana, V (volume), P (pulsa), C (faktor kalibrasi), T (waktu sekon). Rumus diatas merupakan dasar dari perhitungan sensor. Setelah dilakukan kalibrasi, ditemukan rumus yang lebih akurat. Node juga dapat menerima perintah untuk membuka/tutup kran solenoid dari webserver. Flowchart node ditunjukan oleh Gambar 7.

\section{B. Perancangan Webserver}

Webserver berfungsi sebagai kolektor data-data yang dikirim oleh node melalui jaringan WSN. Webserver digunakan sebagai interface antara jaringan WSN dan operator. Melalui Webserver, operator dapat mengendalikan solenoid valve yang terpasang pada node. Webserver dirancang menggunakan mikrokontroler raspberry pi 2 . Raspberry pi dipilih karena dapat terkoneksi ke jaringan Internet melalui Wifi dongle. Selain itu penggunaan sistem operasi raspbian pada raspberry pi memungkinkan adanya interface dan tampilan yang memudahkan penggunaan sistem oleh operator. Data dari node sensor akan diterima raspberry melalui serial usb port yang terhubung ke xbee menggunakan perangkat usb xbee adapter. Data yang diterima raspberry merupakan data yang sudah diolah arduino ke dalam satuan Liter. Data tersebut akan masuk ke tampilan GUI (Graphical User Interface) yang deprogram dengan Python dan ekstensi TKinter. Selain ditampilkan, data tersebut juga dikirim kepada thing speak dengan httplib. Flowchart webserver ditunjukan oleh Gambar 8.

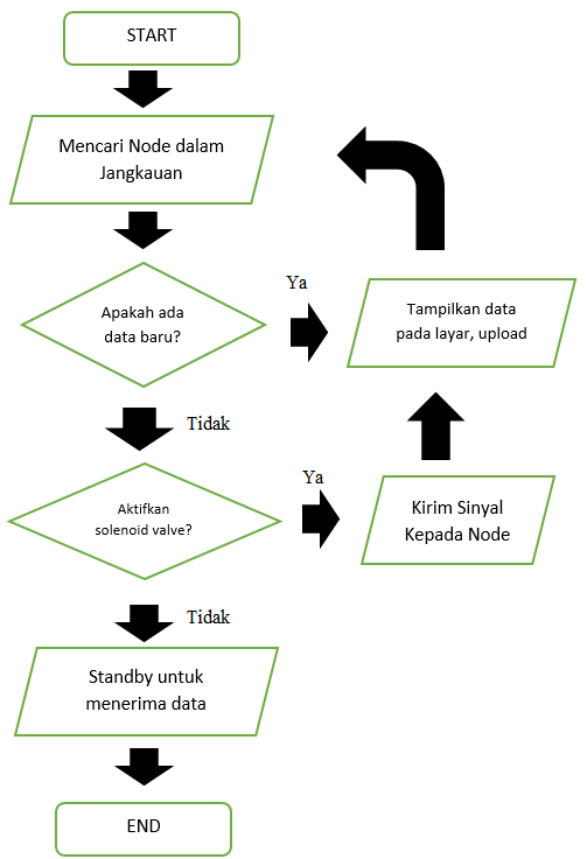

Gambar 8. Flowchart sistem pada webserver.

\section{HASIL PENGUJIAN}

Pada sistem ini telah dirancang 2 buah node dan 1 buah webserver yang terhubung dalam jaringan WSN. Pada sistem dilakukan pengujian kalibrasi sensor aliran air. Pulsa keluaran dari sensor dikalibrasi terhadap volume air yang melalui sensor. Data ditunjukan oleh Gambar 9.

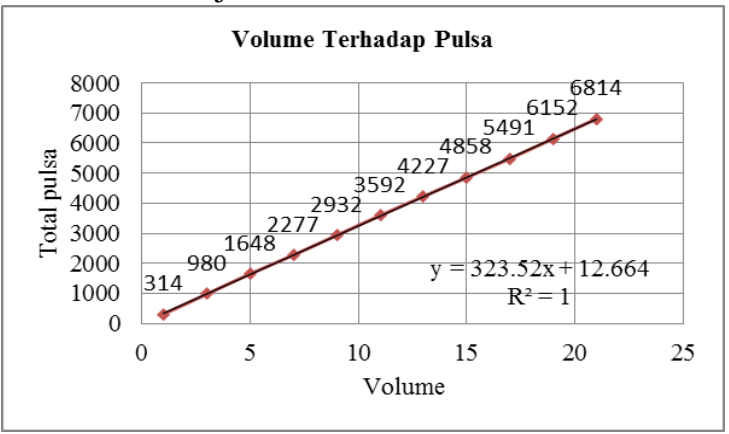

Gambar 9. Grafik hubungan volume terhadap pulsa. 
Berdasarkan Gambar 9 diketahui bahwa hubungan pulsa dan volume air adalah linier. Pengukuran selanjutnya adalah hubungan debit air terhadap pulsa. Pengukuran dilakukan dengan melewatkan 1 liter dan 2 liter air pada sensor dalam variabel waktu yang berbeda. Hasil pengukuran ditunjukan oleh Gambar 10.

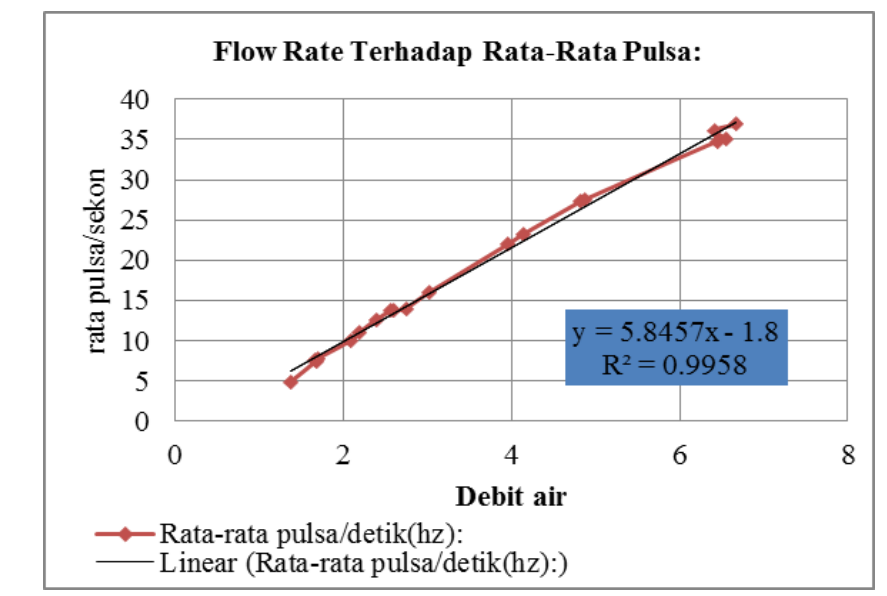

Gambar 10. Hasil pengukuran debit air terhadap pulsa

Berdasarkan gambar 10 diketahui fungsi debit air terhadap pulsa persekon. Fungsi persamaan (2) digunakan dalam perhitungan pada arduino.

$$
Q=\frac{P+1,8}{C}
$$

Dimana $\mathrm{Q}$ adalah debit air, $\mathrm{P}$ adalah pulsa dan $\mathrm{C}$ faktor kalibrasi $(5,847)$.

Pengujian selanjutnya adalah jangkauan dari node sensor. Uji coba dilakukan dengan perangkat lunak XCTU. Hasil pengukuran ditunjukan oleh Tabel 1 .

Tabel 1.

Pengukuran Jangkauan Xbee Pada Node

\begin{tabular}{cccccc}
\hline \hline $\begin{array}{c}\text { Jarak } \\
(\mathrm{m})\end{array}$ & \multicolumn{2}{c}{ Sinyal $(\mathrm{dBm})$} & TX & Paket & $\begin{array}{c}\text { Paket } \\
\text { Literima }\end{array}$ \\
\hline $0 \mathrm{~m}$ & -27 & Remote & Error & Hilang & Dil \\
$2 \mathrm{~m}$ & -31 & -34 & 1 & 0 & 99 \\
$4 \mathrm{~m}$ & -35 & -36 & 1 & 0 & 99 \\
$6 \mathrm{~m}$ & -36 & -38 & 1 & 0 & 99 \\
$8 \mathrm{~m}$ & -38 & -40 & 1 & 0 & 99 \\
$10 \mathrm{~m}$ & -38 & -40 & 1 & 0 & 99 \\
$12 \mathrm{~m}$ & -46 & -50 & 1 & 0 & 99 \\
$14 \mathrm{~m}$ & -48 & -49 & 1 & 0 & 99 \\
$16 \mathrm{~m}$ & -48 & -50 & 1 & 0 & 99 \\
$18 \mathrm{~m}$ & -53 & -56 & 1 & 0 & 99 \\
$20 \mathrm{~m}$ & -57 & -59 & 7 & 0 & 93 \\
$22 \mathrm{~m}$ & -51 & -53 & 1 & 0 & 99 \\
$24 \mathrm{~m}$ & -51 & -53 & 1 & 0 & 99 \\
$26 \mathrm{~m}$ & -55 & -56 & 1 & 0 & 99 \\
$28 \mathrm{~m}$ & -61 & -63 & 28 & 5 & 67 \\
$30 \mathrm{~m}$ & -56 & -61 & 21 & 3 & 76 \\
$32 \mathrm{~m}$ & -59 & -61 & 5 & 1 & 94 \\
$34 \mathrm{~m}$ & -59 & -61 & 3 & 0 & 97 \\
$36 \mathrm{~m}$ & Tidak & Tidak & 100 & 0 & 0 \\
& terbaca & terbaca & & & \\
\hline \hline
\end{tabular}

Selanjutnya pengujian dilakukan terhadap kualitas jaringan WSN. Pengujian dilakukan dengan menempatkan node pada jarak 20 dan 40 meter dari webserver. Hasil pengujian ditunjukan oleh Tabel 2.

Tabel 2.

Hasil Pengukuran Kualitan Jaringan WSN.

\begin{tabular}{cccccc}
\hline \hline Pengirim & Penerima & Jarak & \multicolumn{2}{c}{ Sinyal $(\mathrm{dBm})$} & Presentasi \\
& & & Local & Remote & Kesuksesan \\
\hline XCTU & Node 2 & $20 \mathrm{~m}$ & -55 & -58 & $99 \%$ \\
XCTU & Node 1 & $40 \mathrm{~m}$ & -55 & -58 & $54 \%$ \\
\hline \hline
\end{tabular}

Pengukuran free space path loss dilakukan dengan menggunakan rumus 3 .

FSPL $(d B)=20 \log (d)+20 \log (f)+c$

Dimana d adalah jarak $(\mathrm{km})$, f adalah frekuensi transmisi data(Ghz) dan c adalah konstanta $(92,45)$. Hasil perhitungan ditunjukan oleh Gambar 11. Berdasarkan grafik tersebut diketahui bahwa semakin jauh jarak pengiriman semakin besar rugi-rugi sinyal yang hilang. Hal ini sudah sesuai dengan teori.

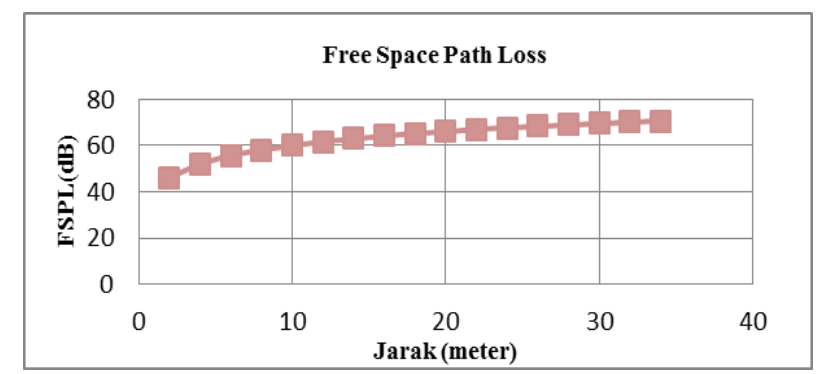

Gambar 11. Grafik pengukuran free space path loss.

\section{KESIMPULAN DAN SARAN}

Pada penelitian ini telah dibuat suatu aplikasi Wireless Sensor Network untuk pembacaan meteran air. Jaringan terbukti terhubung dalam mesh network dimana setiap node bersifat homogen sehingga dapat melakukan data-hoping. Pengujian dilakukan dengan mengukur jangkauan Xbee, dimana diketahui bahwa jangkauan maksimal adalah 34 meter dengan kuat sinyal local $-59 \mathrm{dBm}$ dan sinyal remote $-61 \mathrm{dBm}$. Hasil pengukuran menunjukan bahwa node 2 dengan jarak 20 meter memiliki kuat sinyal local $-55 \mathrm{dBm}$ dan remote $-58 \mathrm{dBm}$ dengan tingkat kesuksesan pengiriman $99 \%$. Node 1 dengan jarak 40 meter dari sumber sinyal memiliki kuat sinyal local $55 \mathrm{dBm}$ dan remote $-58 \mathrm{dBm}$ namun dengan tingkat kesuksesan paket terkirim sebesar 54\%. Hasil penelitian menunjukan bahwa data dari sensor dapat terkirim dengan baik dan dapat diakses secara online. Perangkat node yang telah dirancang memiliki jangkauan maksimal 34 meter dan kesuksesan pengiriman data $54 \%$ pada jarak 40 meter. Oleh karena itu, perangkat dapat dirancang menggunakan Xbee-Pro yang memiliki jangkauan maksimal 90 meter.

\section{DAFTAR PUSTAKA}

[1] "Laporan kondisi muka air waduk," 2014. [Online]. Available: http://sda.pu.go.id/produk/newsmain_list.php?qs=Evaluasi Kondisi SDA.

[2] S. Shafie, S., \& Kawahito, "A Wide Dynamic Range CMOS Image Sensor with Dual Charge Storage in a Pixel and a Multiple sampling technique," SPIE-IS\&T, vol. 6816, pp. 1-9, 2008.

[3] D. International, "Xbee S1 802.15.4 RF Modules," 2016. [Online]. Available:

https://www.digi.com/pdf/ds_xbeemultipointmodules.pdf. 
[4] E. C. I.F Akyildiz, W. Su , Y.Sannarasuramaniam, "Wireless Sensor Networks: a Survey." 2002.

[5] "Wireless LAN Medium Access Control (MAC) and Physical Layer (PHY) specification," IEEE, 2012.

[6] P. Gawande, S. Desmukh, "Raspberry Pi Technology," Int. J. Adv. Res. Comput. Sci. Softw. Eng., vol. 5, pp. 37-40, 2015. 